\title{
Against the Tarbiyah's Symbolism of Hijab: Feminism, Islamic Conservatism and Reconstruction of Hijab Symbolism in Indonesia
}

\section{Ayu Regina Yolandasari*}

Ewha Womans University, South Korea

\begin{abstract}
Although Indonesia is the largest Muslim country in the world, the way of how Muslims dress had never been a major focus of Islamic practice until the 1980s. The promotion of a particular Islamic dress code, especially hijab (veil), started in the early 1980s on Indonesian campuses. Since the Reformasi in 1998, the wearing of hijab has grown significantly along with the spread of the Tarbiyah movement, a transnational Islamist movement affiliated with the Muslim Brotherhood from Egypt. The rise of Islamic conservatism has targeted women to be controlled through their dress and caused Indonesian women to lose their freedom to decide whether they want to wear hijab or not. To fully understand this controlling mechanism, this article explores how the Tarbiyah movement has constructed and utilized the symbolization of $h i j a b$, and the weakness of the movement in enforcing its conservative values to its Muslim women members. Such exploration may direct us to a counter-strategy against the values. Based on in-depth interviews with four former Tarbiyah activists who have been active in feminism, this article examines the way the Tarbiyah controls its female activists through the hijab symbolization and how feminism has helped these activists to detach themselves from the movement. Thus, this article will make an important point on how feminism contributes to the battle against Islamic conservatism in Indonesia.
\end{abstract}

\section{Key Words}

The Tarbiyah movement, feminism, veil, hijab, Islamist groups

\footnotetext{
" Corresponding author:

Ayu Regina Yolandasari

Address: Jalan Pala No. 5A, Komplek Pasir Indah, Kaligandu, Serang, Banten Province, Indonesia 42116.

Email: aryolandasari1312@gmail.com
} 


\section{Introduction}

"I really want to die. There's no point I live my life," a friend of mine texted me after being severely bullied by her friends due to her decision to remove her hijab. "No wonder that you're poor! It's all because you are getting away from God by removing your hijab," one of the texts she got says. She had been removing her hijab for 4 days and verbally abused since the first day she went out in public without her hijab. Other than her, there was also Rina Nose, a celebrity who had been intensely attacked on social media for no longer veiling. In her first Instagram picture without her hijab, she had received hundreds of thousands of comments in a few days. People not only kept asking why she made the decision but also aggressively expressing their sadness, disappointment, even rage. She had been severely accused of toying with Islam and changing her religion. Although she took down the picture and turned off the comment section of her social media, the insult continued through other media platforms.

The unveiling has been a difficult decision for Indonesian Muslim women in Indonesia nowadays. In an interview, Rina Nose asserted that she had been wearing a hijab for only about one year and prepared herself for six months before she finally took off her hijab. This decision made her receive a lot of social pressure on social media. However, committing to wearing the hijab is not easy for Indonesian Muslim women. Another friend of mine texted me and said that she wanted to wear a wide-loose hijab, the so-called syar'i hijab, but she was not sure about it. She said: “... since I work in sport, I'm afraid that I will not be able to maintain my hijab and it will give a sort of impression that I'm just playing with my religion." Those examples show that Indonesian Muslim women are no longer free to wear what they want to wear or not to wear what they do not want to wear.

Indonesia is not an Islamic state although it is the largest Muslim country in the world. Indonesian Muslims are regarded as the representatives of moderate Islam in the world (Hakim 2016). However, LIPI (Lembaga Ilmu Pengetahuan Indonesia [the Indonesian Institute of Science]), reported that radicalism and fundamentalism in Indonesia have been spread and strengthened among Indonesian Muslims since the era of Reformasi in 1998 (Lestari 2016). It has caused an increasing number of intolerance acts such as attacks on non-Muslims' worship places. It also leads to the ruling of certain kinds of dress codes for women (Wieringa 2015). Hijab was not a major focus of the Islamic practice before 1980 (Salim 2015). The promotion of hijab-wearing or veiling in Indonesia was initiated by state university students who had an affiliation with the Muslim Brotherhood (Ikhwanul Muslimin), an Islamist group from Egypt. Since after, through 
the Tarbiyah movement in campuses in Indonesia, the promotion of hijab wearing continues and the symbolism of hijab has been changing over time, from a symbol of Islamic identity, resistance to Western domination, freedom of expression, to a symbol of piety. Later on, the changes then affected people's attitudes toward hijab and Indonesian Moslem women.

As someone who had committed to wearing a hijab for 12 years until 2016, I personally had been experiencing the dynamic changes of hijab symbolism and its impact on me as a woman. When I decided to wear hijab, people were quite resistant to my decision since hijab was stigmatized as a symbol of women's involvement in a certain Islamic extremist group. I had also experienced a short period when women could freely wear and take off their hijab anytime they want. Later on, along with the promotion of hijab as the symbol of Moslem women's identity and piety, I also experienced the growing pressure for women to wear a hijab. Indonesian Moslem women kept losing their freedom to veil or unveil due to the institutionalization of hijab-wearing in certain areas or institutions in Indonesia and the possibility to get bullied when a woman decided to unveil.

Despite the symbolism, there are various reasons why a woman decides to wear a hijab such as religious reasons, local or institutional regulation, psychological/conformity, political, fashion (Juneman 2010), and advocacy strategy (Suryakusuma 2007). As for the reason to unveil, a study by Juneman (2010), shows that two out of four informants of his study decided to not wear hijab anymore after their encounter with non-Islamic activism. Moreover, one of them testified that her involvement in women's activism has changed the way she perceived her hijab and decided to take it off. Nevertheless, less is known the correlation between the decision to veil or unveil and women's activism, especially in the Tarbiyah movement as the one that initially promoted the hijab-wearing and in feminism as the movement which is known in Indonesia as a Western product so that is against the veiling.

Therefore, this article aims to give an understanding of the intersecting issues of veiling, feminism, and Islamist activism in the context of Jakarta as the capital city of Indonesia, the major target of hijab-wearing promotion by the Tarbiyah Movement. The research for this article was conducted through the exploration of women's activists' subjectivity, focusing on women who had been involved in the Tarbiyah movement and moved to feminism. Therefore, this article mainly aims to explore how women's activism in the previously Tarbiyah movement and currently feminism 
affects the way women's activists construct, deconstruct, and reconstruct the hijab symbolism and whether it also affects the decision to veil or unveil? This article attempts to answer the following three main questions: How was the symbolism of hijab constructed by the Tarbiyah movement and functioned as the means to discipline its female members' bodies?; how did the ex-female member of the Tarbiyah movement question and realize the negative ideology embodied in the symbolism of hijab constructed by the Tarbiyah movement? (3); and how did the involvement in feminism affect the ex-female members of the Tarbiyah movement to reconstruct the symbolism of hijab and (un)veil themselves?

Qualitative research was conducted to answer the above-mentioned research questions by using a literature review and in-depth interviews as data collection techniques. The literature review focused on the issues of hijab, the Tarbiyah movement, and feminism in the context of Indonesia. Using a snowball sampling technique, the in-depth interviews were conducted with four subjects of research who did their activism in Jakarta. They are former activists of the Tarbiyah movement who have moved to the feminist movement. Some still wear hijab and others do not (Tabel 1).

Table 1

The Subjects of Study

\begin{tabular}{|c|c|c|c|c|c|}
\hline Subject & Age & $\begin{array}{c}\text { Marital } \\
\text { Status }\end{array}$ & Education & Occupation & Veil/Unveil \\
\hline AF & 32 & Married & $\begin{array}{c}\text { Bachelor Degree } \\
\text { in Social and } \\
\text { Political science }\end{array}$ & $\begin{array}{c}\text { Researcher and } \\
\text { writer on gender } \\
\text { issues and Islam }\end{array}$ & Veil \\
\hline DS & 24 & Single & $\begin{array}{c}\text { Bachelor Degree } \\
\text { in Law }\end{array}$ & $\begin{array}{c}\text { Gender analyst } \\
\text { for a legal aid } \\
\text { institution }\end{array}$ & $\begin{array}{c}\text { Veil } \\
\text { (Considering to } \\
\text { unveil) }\end{array}$ \\
\hline RN & 31 & Married & $\begin{array}{c}\text { Master Degree in } \\
\text { Gender Studies }\end{array}$ & $\begin{array}{c}\text { Founder of } \\
\text { a feminist } \\
\text { community of the } \\
\text { sexual harassment } \\
\text { issue }\end{array}$ & Veil \\
\hline CU & 26 & Single & $\begin{array}{c}\text { Bachelor Degree } \\
\text { in Social Science }\end{array}$ & $\begin{array}{c}\text { An employee } \\
\text { of an NGO for } \\
\text { gender and sexual } \\
\text { diversity issues }\end{array}$ & Unveil \\
\hline
\end{tabular}


There were three sets of questions for the interview. The first set asks the subjects' involvement in the Tarbiyah movement, from the first exposure until they finally left the movement. The second set explores how they initially veiled themselves and made changes to their hijab. It also questions their motivation and feeling regarding the initial decision to veil and the changes they have made. Lastly, the third set of questions asks about their activism in the feminist movement, starting from their first exposure until the recent one. The interview was conducted in person from October until September 2017. There was also a further inquiry process conducted by email until December 2017 to make sure that my understanding of the experience they have told was correct and to have their confirmation that the information I would put on the report was safe enough for their confidentiality.

\section{The Issues of Hijab, Tarbiyah, and Feminism in Indonesia}

Historically, according to Salim (2015), dress had never been a major focus of Islamic practice in Indonesia before 1980. Kerudung or selendang which partially covered women's hair was considered sufficient to fulfil the Islamic advice to cover female bodies. It was the 1979 Iranian revolution that led to an increase in the promotion and the wearing of Middle Easternstyle veils and other forms of Islamic dress in Indonesia. Hijab in Indonesia was initially promoted by state university male students affiliated with a transnational Islamist group Ikhwanul Muslimin(IM[Muslim Brotherhood]) whose dakwah aimed to counter Western cultural and political hegemony. The term "Islamist" refers to a fundamental or radical Islamic group that has a literal understanding of the Quran and Hadith (Albana 2017). The Indonesian Tarbiyah movement also emphasizes the concept of Ikhwanul Muslimin's dakwah (Rinaldo 2013). Therefore, veiling becomes not only a marker of Islamic identity but also a form of opposition to perceived Western cultural domination in Indonesia. In response to the promotion, the New Order government intermittently took actions against the practice. Effendy (2003) explained that in 1982, the government formulated the policy to prohibit students from wearing hijab in public and non-Islamic schools. In 1991, the policy was taken down. According to Machmudi (2008), the Tarbiyah movement through its Campus Activist of Dakwah (ADK) started to spread its ideology in secular and best campuses in Indonesia such as the University of Indonesia (UI), Bogor Agricultural Institute (IPB), and Bandung Institute of Technology (ITB). Besides, in Indonesia, Prosperous Justice Party (Partai Keadilan Sejahtera [PKS]) has been well-known as part of IM (Burdah 2017). According to Rinaldo (2013), most PKS women 
began their involvement in the group through their initial involvement in Moslem study group, Moslem student activism or Tarbiyah networks, and some also joined with their husbands. PKS women's views on marriage, family, and gender are more conservative than other Islamic groups since they are part of the textualist milieu. Pious practices such as ruling the Moslem clothing for women help to instil in party members a sense of the essential difference between man and women, one that is respected through bodily separation. A study conducted by Turmudi (2016 in Ramadhini 2017) shows that the spread of hijab wearing on the campus was more effective if the students organized it because it could strengthen religiosity in terms of the implementation of hijab as a daily outfit. However, according to Suryakusuma (2013), Muslims in Indonesia are becoming increasingly concerned with formalism such as clothing and rules, rather than spirituality and faith after the Reformasi 1998.

As quoted in Fujita (2015), Dewi Candraningrum, the lecturer at Muhammadiyah University Surakarta and the author of the book Negotiating Women's Veiling, stated that after Suharto was toppled in late 1998, the headscarf became a symbol of freedom for women. But, conservative activists pushed to make veiling mandatory afterwards. A feminist anthropologist Saskia E. Wieringa (2015) also mentioned that the growing influence of conservative Islamic teachings has led not only to the increasing numbers of intolerance towards other Islamic groups and sexual minority, but also the ruling of a certain kind of dress code for women. Due to the significant escalation of the process of Islamization after Suharto, the changes in the interpretation of the Quran occurred. Therefore, at the national level, dress and modesty have been a major focus for change following the lead of the Saudi Arabian government's translation. The new Indonesian version of the Quran interpretation released by the Ministry of Religion in 2007 mandated more covering of women's bodies than the older version one, which was released in 1970 and was more flexible (Salim 2015).

In No Longer a Choice, Eve Warburton (2007) also explained that since the fall of the New Order regime, there has been a serious shift in Indonesian society concerning the hijab. In the past, most Indonesians considered Islamic dress as a matter of private interpretation. In contrast, since Reformasi, local governments and Islamic institutions have begun to force women to cover and, at the national level, the proposed antipornography laws place restrictions on women's dress and emphasize control of the female body as a tool for social reform. The supporters of these new regulations argue that this is a necessary step for addressing 
what they see as 'moral crises' of Indonesian society, claiming that the veiling of women will create a moral and stable community. Islamic universities have begun enforcing Muslim dress for female students on campus. The proponents of tighter regulations argue that veiling displays a strong religious public image and improves the moral quality of the student community. Meanwhile, in non-religious universities, even where there are no legally enforceable rules, there is growing pressure for women to dress modestly and wear hijab. Warburton also explained that the control of the female body and the promotion of personal morals have become part of a mainstream political approach for addressing Indonesia's complex social and economic problems. The veil is a powerful symbol of Muslim identity and moral control so that enforcing hijab became an easy way for institutions to show their adherence to Islamic principles and commitment to moral reform. In early 2000 , the hijab started to be well-marketized in the fashion industry. Thereafter, the fashion industry of Moslem wear keeps growing significantly as more "young" and attracting urban women to wear hijab as their fashion style. The representative of the Ministry of Cooperatives and SMEs, Euis Saidah, mentioned that there are 20 million people in Indonesia wearing hijab in 2012 and the development of Moslem-wear fashion rose 7\% per year (Noorastuti and Abbdinnah 2012). Therefore, Indonesia has set a target to become a centre for global Muslim fashion by 2020. The government is quite optimistic with the target since Indonesia has become the third country with the highest Moslem wear consumption after Turkey and Iran based on a report by Thomson Reuters and Dinar Standard in the Global Islamic Economy Report in 2012. Besides, within the Organization of Islamic Cooperation, Indonesia is one of the biggest Moslem wear producers and exporters.

Despite the above historical journey of hijab promotion in Indonesia, there are various reasons why Indonesian Muslim women veil themselves. Siti Musdah Mulia (in Juneman 2010) explains that some women wear hijab for theological reasons as they believe that wearing a hijab is an Islamic obligation. Others wear hijab because of local and institutional regulations. Another reason is psychological one in that some attempt to conform with their surrounding in which many women wear hijab. There is also a political reason as some fulfil the demand of certain Islamic groups which utilize Islamic symbols as their political strategy. Lastly, fashion has been the most significant reason for the wearing of hijab in Indonesia, especially after the 2000 s.

In addition, the massive spread and formality of hijab wearing seem to influence women's activism. For instance, Neng Dara Affiah, an Indonesian 
Muslim Feminist, wears a hijab because she comes from a strong pesantren (traditional Islamic learning institution) tradition. She said that wearing a hijab makes it easy for her to be accepted in Muslim communities when she carries out grassroots gender training, gives seminars, or attends Qur'anic recitals and other religious meetings (Suryakusuma 2013). Due to the dynamic changes in the representation of hijab in Indonesia, Lies Marcoes (in Wahid Institute 2007), an Indonesian Muslim Feminist, stated that hijab cannot be interpreted monolithically. "Hijab can be a business field or class identity. It can also become the mean of women's subordination and struggle", she said. In the discussion on The Freedom to Veil held on May $23^{\text {rd }}, 2017$, two Indonesian Muslim feminists spoke about hijab in the context of Indonesia. Nong Darol Mahmada, based on her study on Fatima Mernissi's interpretation of the Quran and Hadith regarding veil, firmly stated that wearing hijab is not an obligation in Islam and Indonesia is socially and culturally different from Arab or Middle Eastern countries. According to her, Indonesian women have more freedom than Middle Eastern women to some extent. Lailatul Fitriyah explained that hijab can be considered as an obligation in one context and not so in another one, and it represents the symbol of oppression in one context and the symbol of women's empowerment in another one in Indonesia. This is in line with Fadwa El-Guindi (1999), a Muslim Feminist who conducted the feminist study on veiling, who said that veiling must be viewed in its historical, socio-cultural, and situational/spatial context to ascertain its meaning and significance.

Juneman (2010) researched the decision of four women who decided to take off their hijab from a psychological and sociological perspective. Through interviews, he found that their decision to veil and unveil is significantly caused by their existential beliefs, a continuous process of Muslim women to formulate and reformulate their way to view a hijab. The belief would be affected by the subject's chronological age as well as their life crisis, challenges, and any form of disturbance cognitively, affectively, or socially. The result of his research shows that the experience of veiling and unveiling is particularly related to the aspect of the symbolic function of hijab itself. However, that aspect could not be separated from other aspects such as logic, social perspective internalization, moral consideration, the limits of social awareness, authority locus, and the coherence of the subject. Thus, the way of valuing oneself as a Muslim woman who wears or no longer wear a hijab has a close relationship with her way to value her own religious and not religious life. Besides, too much emphasis on the concept of sin versus reward and hell versus heaven 
as something they should always be aware of has become the significant factor that affects the aspect of moral consideration. It is also related to the subject's interactions with her family, friends, and her other circumstances. Interestingly, two of his respondents decided to unveil after their encounter directly and non-directly with non-Islamic activism, namely feminist activism. Unfortunately, this aspect was not further explored in the study. Thus, in this article, I will explore more about women's activism concerning the (un)veiling by focusing on the subjectivity of women's activists who had been involved in the Islamist movement but then moved to feminism. More specifically, I will examine the symbolism construction and reconstruction of hijab by the subjects.

\section{The Tarbiyah Movement's Construction and Utilization of the Symbolism of Hijab}

\section{The Construction of Hijab Symbolism}

Most of the subjects of this study wore hijab for the first time in their senior high school. It is only OM who started to wear it at the end of her junior high school, right after she finished the school national examination. However, all of them had worn hijab before they were involved in the Tarbiyah movement which was started by their involvement in liqo. Later, their involvement in Tarbiyah affected the way they perceive what the hijab is and the way they wore their hijab.

The interviews show that each of the subjects had their initial reason and motivation to wear hijab for the first time, which is different from one to another. Unlike the others, DS did not want to wear hijab, but she then wore it because her high school had obliged her to wear one. AF, who had been exposed to the social and political issues in the Islamic world since very young, was motivated to wear hijab to show her Islamic identity as the manifestation of her solidarity with Muslims who had been killed and tortured in the Bosnian war. Besides, like RN, the experience of sexual harassment in public places had also contributed to the decision to veil. AF said:

I feel like it was a form of religious and solidarity statement. The religious statement itself is not in the sense that I can be more pious, but become more secure, and protected. From the identity aspect, this is also part of my Islamic spirit that just found its manifestation. And at the pragmatic aspect, it might protect me from sexual harassment. 
RN also stated the same reason to wear hijab as she said:

Now, I have been in a point that women who wear hijab have the same potency as women who do not wear hijab in terms of becoming the victim of sexual harassment. However, in Indonesia and according to my experience, by wearing hijab, I could have more bargaining positions to fight back. It is like I am bringing my fence everywhere, so if someone keeps violating me I could fight.

Thus, both AF and RN thought that the hijab made them more secure from sexual violence that they had experienced before. While OM, although she was unsure about why she decided to wear hijab, she was motivated to wear one since she was in her second grade of junior high school. It was when she was involved in after-school mentoring in her school's mushola in which she attended discussions on hijab.

Despite the different motivations of why they decided and started to wear hijab, all the subjects admitted that gradually they covered their bodies further by wearing a longer and wider hijab, long skirt, and socks, and covering their arms. Besides, the change in how they covered their body happened when they were involved in the Tarbiyah. The feeling that they were supposed to conform to the group in terms of veiling was one of the reasons why they covered more parts of their bodies (Juneman 2010). As RN explained, the way women in Tarbiyah interacted made her uncomfortable if she did not conform to their veiling "template", by which members had to wear a long hijab that covers her bottom, a long skirt, arm covering, and socks. DS started to wear hijab due to the school rule as her school is affiliated with PKS (an Islamist party) or Tarbiyah. She also admitted that she started to wear a wide and loose hijab as she wanted to conform to her surrounding. OM said: I am thinking that maybe at that time I wore a loose and long hijab because my friends in that group wore that kind of hijab and people valued others based on their hijab". This is confirmed by AF who stressed that: "Besides, they also fixed me..., fixed the way I wore my hijab, the way I do jamaah prayers".

Another reason they covered more parts of their body is related to the symbolism of hijab in the Tarbiyah movement they followed. They realized that in the group, hijab was a symbol of Muslim women's piety. As OM said before, in the group members valued others based on their hijab; the looser and longer hijab one wore, the more pious she was regarded. AF said: 
So, the bigger hijab you wear, the better you are. We measure our piety from the size of hijab. If one wears a short hijab, she will be considered as futur. It is a term in the Tarbiyah movement, which means breaking rope or breaking liqo. The movement members may think that she is losing her faith in Islam.

This is confirmed by RN who said that "So, physical code is so much important for them although it was not visibly written. It has become the indicator of the level of Islamic piety".

This is also in line with DS explanation that in her high school, she learned from her surroundings that hijab was a representation of piety, and a wide hijab meant that the wearer was a pious woman. So, there was pressure from her surroundings that made her wear a loose and long hijab.

Thus, based on the explanation above, the early reason and motivation of subjects to wear hijab are theological, but they then developed into nontheological ones due to the subjects' experiences. The experience of sexual violence led the subjects to wear hijab to feeling more secure. Following school's rules is another reason why they decided to wear hijab. Then, their involvement in the Tarbiyah movement made them cover more parts of their bodies. This is due to the indirect pressure to conform to the "template" showed by their fellows in the Tarbiyah movement as well as the constructed symbolism of hijab as the sign of Muslim women's piety. Then, how the Tarbiyah movement utilized this symbolism?

\section{The Utilization of Hijab Symbolism}

At the end of her first grade in high school, RN decided to wear hijab for the first time. Since after, she started to come to mentoring sessions (liqo) more often in the Tarbiyah movement. She was excited to see her mentor. "At that time, I just started to wear hijab and I became excited to find more information about Islam. I read Islamic books, I came to mentoring sessions more often, and tried to find more places to have discussions on Islam," she explained. She admitted that it was just after she wore hijab for the first time she was interested to have a deeper understanding of Islam. She felt that because she wore hijab, she had to understand Islam more than before. She found the mentoring sessions in the Tarbiyyah movement a way to understand Islam. As seen from RN's experience, hijab wearing affected women's attitude towards religion. In her case, it improved her interest in learning more about Islam and led her to attend actively the mentoring sessions. 
In the other cases, the wearing of hijab interested the senior members of Tarbiyah movement to approach the subjects and get them involved in Tarbiyah activism. As DS explained:

During religious activities in the campus orientation program, they will assess students to be recruited by their appearance first. It will be easy for women to be targeted. They will personally approach those who wear loose and long hijab and long skirt.

Furthermore, once the subjects of my study were involved more actively in the Tarbiyyah movement, they looked similar to other members of the movement in appearance. For instance, like the senior members of the movement, they covered more parts of their bodies. The similarity in appearance then affected their relationship with those outside of the group. As OM said, after she wore her hijab for the first time, her friends identified her as a member of ROHIS (Islamic activism at high schools) because of the sim1ilarity of her appearance with the Tarbiyah members. Her friends who were not from ROHIS felt awkward to her. In the other words, wearing hijab in line with the Tarbiyah's way of wearing hijab created exclusivity. This also affected the level of their militancy, the most important criteria in the further recruitment of Tarbiyah members.

According to Kholis Fuad (in Rahmat 2008), a PKS male activist, the selection system in the Tarbiyah movement prioritize militancy so that the activists' commitment to the vision and mission of the group would not easily fade away. This is proved by the experience of OM. OM was more militant than her friends in her senior high school. She obliged herself to not come late to the liqo and be never absent. But, she became more judgmental toward those of different groups as well those of the same movement. OM said:

Oh, so sad... I was horrible. At that time, I felt like I was the most righteous one. I became so much judgmental to the other different groups also to my own. I could not accept even if someone needed to accompany her mother. I would say that the liqo is more important. I believe so much in a verse of the Quran, surah AtTaubah verse 41, that said, "Go forth whether light or heavy and strive with your wealth and your lives in the cause of Allah. That is better for you if you knew". My group often repeated that verse to motivate us to involve in liqo and any other activities. I absorbed it too well. I did not care about my body condition. Even if I got dizzy, I would come to the liqo. 
This is similar to AF who admitted that she would confront women who removed their hijab. Her militancy made her act "just like a sharia police officer."

Thus, it is why physical code become so much important for the Tarbiyah movement. It is an indicator of members' militancy. According to Kokom (in Rahmat 2008), an activist of the Tarbiyah movement, the moderation of the outfit ruling affected the women activists' level of militancy. It decreased their commitment to Islamic dakwah, their willingness to struggle and sacrifice, and the intensity of their participation in the Tarbiyah activities. She also mentioned that moderation caused them fragile, easily affected by other groups, and withdraw from the Tarbiyah movement.

\section{Questioning the Tarbiyah's Hijab Symbolism}

The life crisis experienced by the subjects of this study was momentum for them to question the Tarbiyah movement. It triggered them to realize patriarchal and heteronormative values embedded in the movement. The following is the detail of the life crisis experienced by the subjects of this study.

\section{Falling Victim to an Abusive Relationship}

Falling victim to an abusive relationship was a moment in which AF realized to leave the Tarbiyah activism. It was not the direct cause of why she detached herself from the movement. Instead, she left the movement after she realized what had made her fall into the unfortunate situation and the lack of support given by the movement. AF admitted that she was the victim of the early marriage doctrine socialized by the Tarbiyah movement. One day, she read a book entitled Indahnya Pernikahan Dini (The Beauty of Early Marriage). Then she hoped to meet a nice guy who would bring her out of the house. Thus, when she met this guy, she thought that by marrying him, she could leave the house soon. Even though he had that commitment, the guy still approached her aggressively and it seemed that he used the commitment to touch and harass her sexually. She was also pressured by her fellows in the Tarbiyah movement. AF said:

They said:"You know, you've become part of our core team, you must know the rules, but why you are still being close to him? Did you get married already?' I was frustrated and because of that pressure, I decided to get married. 
Since the marriage and because of the abusive relationship, AF became less active in the Tarbiyah and was no longer involved in the movement. She could not develop herself because of being busy with her personal struggle. AF tried to tell her seniors in the movement about her plan to divorce. But, they told her to rethink her decision and discouraged her. AF was disappointed. She said:

I kept silent for so long. I wanted to leave the relationship but I was too scared. I was terrorized. I needed someone to tell me that I am not alone. I already had two kids at that time. He said: "Who will be interested in you if we get a divorce?! You will just be a widow with two kids". I couldn't stand it anymore. The Tarbiyah didn't support me. It didn't give any spirit of resistance against personal oppression. We supported Palestine even did the demonstration for Palestine. But, when we faced a personal problem, we had to fight alone.

Amidst abusive marriage and was no longer involved in the Tarbiyah, AF was introduced to feminism when she took two classes on politics and women. In the classes, she started to be empowered. Moreover, the lecturer was empowering and supportive. When she told the lecturer about her family condition, her lecturer supported her plan to divorce. She found her spirit of resistance again and was triggered to question herself: "We (women) are interested in politics of violence and resistance, but why do we allow ourselves to be oppressed? We (women) have a high political will when we see the injustice here and there, but when it happened in our domestic sphere, why can we just be silent?".

\section{Falling Victim to Sexual Violence}

All the subjects of this study experienced sexual violence. The occurrence of sexual violence itself was not enough to empower and trigger them to question the values that were cultivated by the Tarbiyah. To empower them and change their attitude towards Tarbiyah and hijab, it needed to be mediated with another event that could raise the subjects' consciousness of becoming the victim and that they were not the cause of the sexual violence.

In the case of DS, sexual violence that happened to her after she was involved in the Tarbiyyah movement did not immediately trigger her to question the negative values that had been cultivated by the movement. Instead, she tended to blame herself. She said: 
It was in 2012. I experienced sexual violence from my male friend who is a member of the Tarbiyah as well. No one knows this. I just told my high school friend who doesn't know how to react to that. She just asked me to learn from my mistake. So, I blamed myself. Why did I allow myself to be with him by myself, just two of us? We were not supposed to have an intimate relationship, but I was a rebel. I was not his girlfriend, but we were close. One day he kissed me forcefully. But then he repeated kissing me three or four times. I kept coming back to him because I thought that he was a responsible one. I didn't know that it was sexual violence.

It took two years for DS to find out that it was sexual violence and she became a victim. In 2014, she attended a seminar on sexual violence at the University of Indonesia. The speaker shocked her and she felt empowered. DS said: At that time, I remembered what had happened to me in 2012. Oh my God! It (sexual violence happened to her) was not my fault! I felt empowered!".

This consciousness of being the victim empowered DS. She realized that there was something wrong with the value she had internalized from the Tarbiyah movement. She said:

I felt like, this was supposed to be able to be prevented. Not the sexual violence itself, but how I was supposed to deal with that. To whom should I report it and for sure not blame myself. And I think one of the problems that caused this was how I was educated and the circumstances where I live. How Islam teaches about women is not empowering at all. Not empowering at all. This make the cases like this (sexual violence) will never be exposed because people will just keep silent and women will just blame themselves. This enraged me, but I did not know to whom because my culture and religion talk like this (blaming the victim). I did nothing bad to anybody. How come this horrible thing happened to me? They said if we are good, we will receive the good. In fact, it is not like that.

\section{Being Lesbian}

In 2011, OM started to question her sexuality. This led her to learn about female sexuality and explore more about her own. It was not easy for her because she was still involved in liqo. She stopped her activities in tarbiyyah including the daurah due to an accident and her leave of absence. So, at that time, her interaction with the movement had been lessened. 
In her exploration of her sexuality, she tried to find the Quranic verses, hadith, and ulama's jurisprudence on homosexuality. She found that there is nothing that talks about same-sex attraction, but same-sex sexual activities or behaviour. At that time, she did not think that she would do the sexual activities either. However, she was also exposed to a narration that said that homosexuals deserve to be killed. This kind of narration made her upset as she felt that her feeling about a woman was given by God. Then she could not understand why she was supposed to be punished for something that she never asked for.

In her liqo and her circle of friends, she tried to bring up the issues of LGBT to be discussed. But, these were not positively responded to. In her liqo, she shared that she wanted to be a counsellor. But, her murrobiyah (a feminine form of murrobi or mentor) warned her not to become a counsellor for LGBT. In her circle of best friends, she asked what they would do if they had a family member who is LGBT. Her friends told her that they were unsure, but probably they could not accept him or her. Thus, OM realized that her sexuality was something that she could not talk to them although she had tried to give some hints.

\section{Being Feminist}

$\mathrm{RN}$ had been interested in women's issues before she was involved in Tarbiyah. It was when her identity as a feminist was bothered by the Tarbiyah movement that she no more tolerated different values between her and the group.

During the 2014 presidential election, the liqo became a medium for spreading hatred against Chinese communities, communists, and feminists. While RN identified herself as a feminist, she decided to leave the Tarbiyah in 2015 because she could not stand it anymore. She told her friends that she could not involve anymore in the movement and would find her spiritual journey. She said:

I decided not to involve [in the Tarbiyah movement] anymore even until now. Before, I thought that if I was no more there, I wouldn't be able to reach them out anymore. I tried to survive there, in the system, because I wanted to disseminate my thought about gender and give them a different perspective. But then I realized, whom I was trying to save? I thought that I needed to save myself, so I left and decided to continue the struggle through another way.

The life crisis that had happened to the subjects of this study triggered them to question the negative values, such as misogynist, patriarchal and 
heteronormativity, embedded in the Tarbiyah movement (Shaiks and Maguire 2007). It refers to the violence they experienced, such as falling victim to an abusive relationship and sexual violence, as well as an indirect attack on their sexual and feminist identity. Moreover, the lack of support from the Tarbiyah members led the subjects to find another source of support. This led to their detachment from their Tarbiyah group and the movement. The exposure to feminism when they had to deal with their life crisis empowered and triggered them to question the values that had been internalized by the Tarbiyah and later led to the change in their attitude toward the movement. As a result, this change affected their attitude toward their hijab. The wearing of hijab is caused by the commitment to a group which is manifested through the hijab symbolism according to the group's construction of it which is socially legitimized (Ramadhini 2017).

\section{The Involvement in Feminism and the Reconstruction of Personal Hijab Symbolism}

The violent reality facing the subjects of this study triggered them to question the negative patriarchal and heteronormative values which had disempowered them. The lack of support they got from their fellow members and the exposure to feminism helped them to detach from the movement. Besides, it helped them to reconstruct the symbolization of hijab which then led them to take their hijab off or not. Thus, in this part, each of the subjects' reconstruction of the hijab symbolization will be explained. Then, it will show how they internalized the meaning of being (un)veiled.

\section{Re-Veiling as the Means to Negotiate and Be Socially Accepted}

Sexual and domestic violence experience made AF realized that the Tarbiyah movement would not support her and other women who experienced crises. She wore hijab when she was 17 years old and since then it became a statement of her Islamic identity, struggling, and personal convictions. But, in 2016, AF decided to remove her hijab. She said: "I've always tried to be a good Muslim woman, but I kept falling into traumatic experiences and was disappointed with my convictions".

AF admitted that when she removed her hijab for the first time, she felt free. For her, it felt like she released the burden and horrible experiences in the past. But at the same time, AF also questioned if it was really her. She had unveiled for 8 months when I met her. For her, it was also a battle. Her mom was furious about her decision to unveil. After eight months 
she had unveiled and had struggled on it, she managed to negotiate with her circumstances by changing her perspective regarding hijab. Wearing hijab was no longer a burden afterwards. She did not consider hijab as the symbol of a certain Islamic identity which bothered her life. Rather, it became her way to negotiate to be accepted by her family, her people in Aceh, and the Islamic community. AF realized that freedom could not be attached and symbolized by a piece of cloth. She found that by doing all this she got a kind of freedom, but she lost other things when she veiled and unveiled.

\section{Unveiling as the Way to Gain the Freedom of Expression}

The consciousness of being a victim of sexual violence led DS to realize that her Islamic circumstances, namely the Tarbiyah movement, did not enable her to be empowered. Not only did she detach from the movement, but also managed to find her space in her workplace. Besides, it led her to the point in which she was no longer comfortable with the hijab that she wore. Hijab lost its significance for DS. She said:

Because I've learned feminism, I felt like it is not anybody business how long my hijab is. So, now I feel that the hijab is only an accessory like a hat or jacket. Moreover, feminism also has taught me that there is a lot of different interpretation regarding $h i j a b$, even there's also an interpretation that says it is okay to not wear it. [...] I wanted to express myself through what I wear, and it cannot be done if I wear hijab. By expressing ourselves it means that we have power over our own body, right? I envy my feminist friends. They can wear any kind of clothes, any colour of lipstick. They seem to have their freedom.

In March 2017, DS tried to unveil for a few days when she came to Coldplay's concert. When she removed her hijab for the first time, she thought that she would feel guilty or uncomfortable. In fact, she was fine with it. Moreover, she was finally able to wear an outfit she wanted to wear. When she informed me on December $12^{\text {th }}, 2017$, DS had removed her hijab in her office for two or three months. She felt happy and tried to wear anything that she had not been able to wear when she was still veiling.

\section{Veiling to Own Her Body}

Regardless of the heated debates on hijab, RN felt that wearing hijab made her own her own body. This is related to her relationship with her mother who always controls her body. RN said: 
Even when I was 30 years old, my mom still protested the way I dressed and asked me to wear her chosen dress. She always complained about my things, my hair, anything. But now I don't care anymore. When I wear hijab, my family support me, including my mom. Previously, when I wore a long and wide hijab until my bottom, she didn't like it. For her, I was too conservative. But now when I am more stylish, she wants me to wear my hijab like before. She becomes more religious according to her definition.

$\mathrm{RN}$ no longer wore hijab until her bottom and opted to wear pants rather than a long skirt. But, her hijab was wide enough to cover her chest. She explained that it was related to her multiple experiences of sexual violence. She perceived her breast as the source of sexual harassment. She was and is still uncomfortable with her breast. She does not want to look at them and when she has sexual activities she did not want to talk about her breast. She felt that her breast was the source of what had happened to her all this long. So, she kept wearing hijab that covers her breast.

\section{Unveiling as the Symbol of Rebellion}

Removing her hijab became OM's way to distinguish herself from the members of the Tarbiyah movement. She said:

I don't want to look like that group anymore, I don't want to be identified as part of them. So, I kept removing the things that made me look similar to them. I removed my arms covering. I remove my under-veil. I folded my sleeves. I am not comfortable even just with wearing a thin hijab. And after I told you this, I am thinking that maybe at that time I wore a wide hijab because my friends in that group wore that kind of hijab and they valued others according to their hijab. Now, I don't want to be part of that group. It is very uncomfortable.

Moreover, removing hijab was an expression of OM's rebellion against the ideas on sexual violence and hijab promoted by the Islamist groups. She thought that she disagreed with the idea that hijab protects women from sexual violence. She could not accept the idea that she needs to do something, in this case wearing hijab, to prevent men from doing sexual harassment to her. This made her rethink and question why she wore hijab if she didn't believe in it anymore.

Despite her willingness to fully unveil, OM wore hijab on certain occasions and circumstances where her friends from the Tarbiyah 
movement lived and did their activities. This was her way to respect her friends who still held the conservative values of hijab. Moreover, she needed to keep veiling to support her work to infiltrate into the Islamist groups' discussion on LGBT. She wore hijab more flexibly. She did not wear hijab whenever she wanted and she wouldn't mind wearing it in a condition that she needed to wear it like when she needed to negotiate with conservative Islamic groups on certain issues. She believed that hijab was only a piece of cloth or accessory, but she also regarded it as having power that she could exercise in certain occasions and contexts.

\section{Conclusion}

This article has shown that women's activism in their former Tarbiyah movement and current feminism affected the way they constructed, deconstructed, and reconstructed the hijab symbolism and influenced their decision to wear or not to wear hijab. Despite different motivations on why the subjects of this study decided and started to wear hijab, the involvement in the Tarbiyah movement affected the way they covered themselves. They gradually covered more parts of their bodies just like their fellow members in the movement in conformity with the hijab symbolism constructed by the Tarbiyah movement. Hijab was regarded as a symbol of Muslim women's piety as the members of the movement valued others by the kind of their hijab. The wider hijab a woman wore, the more pious she was regarded. Hijab and dress code were indicators to measure the militancy of Tarbiyah female activists.

The life crisis experienced by the subjects of this study such as falling victim to gender-based violence and the realization that they were feminists and lesbians was the momentum for them to question the teachings and values enforced by the Tarbiyah movement. This led them to realize patriarchal and heteronormative values promoted by the movement, which in turn disempowered them. The disappointing attitude of fellow members also brought the subjects of this study to detach themselves from the Tarbiyah movement. The exposure to feminism, when they had to deal with their life crisis, empowered them and changed their attitude toward the Tarbiyah movement. Moreover, this change in attitude towards the movement affected their attitude toward hijab. Their disappointment with the Tarbiyah movement did not necessarily bring them to remove their hijab. The subjects of this study changed their way of veiling their bodies and reconstructing new values of (un)veiling. Thus, veiling and its symbolism constructed by Tarbiyah had no longer the power to determine 
the subjects' behaviour. Their reconstruction of hijab symbolism enabled them to regain control of their bodies and determine whether they would go veiled or unveiled according to certain contexts and situations.

\section{Funding}

The author(s) received no financial support for the research, authorship, and/or publication of this article.

\section{Acknowledgments}

This article was written based on my master's thesis in the Department of Women's Studies at Ewha Womans University, South Korea. I would like to thank Prof. Kim Eunshil for supervising and giving me valuable advice and support for this research and my overall master's education. I also would like to thank all informants for their willingness to be involved in this research and share their valuable experiences. This research was presented in some feminist groups in Korea and Indonesia and at some conferences such as The Empowerment of Women in Indonesia Conference organized by UCLA Center for Southeast Asian Studies, LA, United States, in 2019, and the $1^{\text {st }}$ Bandung International Conference in Social Science (BICOSS), 6-8 July 2021 in Bandung (online) where I received some supportive feedback to the improvement of this article.

\section{Endnotes}

1 Hijab is a term that has cultural and linguistic roots that are integral to Islamic (and Arab) culture as a whole (El-Guindi 1999) and has the meaning "to cover or separate things". In relation to clothing in Islamic teaching, hijab could be defined as Muslim women's modest wear or the Islamic tradition of veiling. In this article, the terms hijab and veil is used interchangeably.

\section{References}

Albana, U. A. 2017. Kaffe 6: Online Lecture on Women and Religious Radicalism. Jakarta: Yayasan Jurnal Perempuan.

Burdah, Ibnu. 2017. “Adakah Hubungan PKS dengan Ikhwanul Muslimin?". Jawa Pos, 1 May.

Effendy, Bahtiar. 2003. Islam and the State in Indonesia. Singapore: Institute of Southeast Asian Studies. 
El-Guindi, Fadwa. 1999. Veil: Modesty, Privacy, and Resistance. New York: Berg.

Fujita, Akiko. 2015. "Hijab Fashion is So Popular in Indonesia.

Non-Muslim Designers Are Getting In on It". The World,

October 7. Retrieved 1 September 2017 (http://www.pri.org/ stories/2015-10-07/hijab-fashion-so-popular-indonesia-nonmuslim-designers-are-getting-it).

Hakim, Rakhmat Nur. 2016. "Survey Wahid Foundation: Indonesia Masih Rawan Intoleransi dan Radikalisme". Kompas.com, August 1. Retrieved 1 September 2017 (http://nasional.kompas.com/ $\mathrm{read} / 2016 / 08 / 01 / 13363111 /$ survei.wahid.foundation.indonesia. masih.rawan.intoleransi.dan.radikalisme?page=all).

Juneman. 2010. Psychology of Fashion: Fenomena Perempuan [Melepas] Hijab. Yogyakarta: LKiS.

Lestari, Sri. 2016. “Sikap Intoleran 'Kian Meluas' di Masyarakat Indonesia". $B B C$, February 16. Retrieved 1 September 2017 (http://www.bbc.com/indonesia/berita indonesia/2016/02/160222_indonesia_intoleransi).

Machmudi, Yon. 2008. Islamizing Indonesia: The Rise of Jamaah Tarbiyah and the Prosperous Justice Party (PKS). Canberra: ANU Press. Retrieved 1 September 2017 (http://www.jstor.org/ stable/j.ctt24hddh)

Mernissi, Fatima. 1987. Beyond the Veil: Male-Female Dynamics in Modern Muslim Society (Revised Edition). Indiana: Indiana University Press.

Rahmat, M. Imdadun. 2008. Ideologi Politik PKS: Dari Masjid Kampus ke Gedung Parlemen. Yogyakarta: LKiS.

Ramadhini, Eveline. 2017. "Fenomena Merebaknya Jilbab di Universitas Indonesia" (The Spread of Hijab at the University of Indonesia). Wartapilihan.com, February 23. Retrieved 1 September 2017 (http:/www.wartapilihan.com/fenomena-merebaknya-jilbab-diuniversitas-indonesia/)

Rinaldo, Rachel. 2013. Mobilizing Piety: Islam and Feminism in Indonesia. New York: Oxford University Press.

Salim, Delmus Puneri. 2015. The Transnational and the Local in the Politics of Islam: The Case of West Sumatra, Indonesia. Switzerland: Springer International Publishing. 
Shaik, S. and Maguire, D. C. 2007. Violence Against Women in

Contemporary World Religions: Roots and Cures. Cleveland, Ohio: Pilgrim Press.

Suryakusumah, Julia. 2013. "Sexypants and Headscarf: When Minds and Spirits Meet". In Julia's Jihad: Tales of the Politically, Sexually, and Religiously Incorrect: Living in the Chaos of the Biggest Muslim Democracy. Depok: Komunitas Bambu.

Wahid Institute. 2007. "Peta dan Isu Gerakan Perempuan Islam di Indonesia". The Wahid Institute, June 12. Retrieved 1 September 2017 (http://www.wahidinstitute.org/v1/Programs/ Detail/?id=126/hl=id/Peta_Dan_Isu_Gerakan_Perempuan_Islam_ Di_Indonesia).

Warburton, Eve. 2007. "No Longer A Choice". Inside Indonesia, July 14. Retrieved 1 September 2017 (http://www.insideindonesia.org/nolonger-a-choice).

Wieringa, Saskia E. 2015. "Gender Harmony and the Happy Family: Islam, Gender, and Sexuality in Post-Reformasi Indonesia". South East Asia Research 23(1): 1-18. Doi: 10.5367/sear.2015.0244. 
